\title{
Probability of occurrence of the Brazilian spotted fever in northeast of Paraná state, Brazil
}

Probabilidade de ocorrência de febre maculosa brasileira no norte pioneiro do estado do Paraná, Brasil

Flávio Haragushiku Otomura ${ }^{1,2 *}$; Jessé Henrique Truppel ${ }^{3,4}$; Jonas Moraes Filho ${ }^{5}$; Marcelo Bahia Labruna ${ }^{5}$; Diogo Francisco Rossoni ${ }^{6}$; Rubens Massafera ${ }^{7}$; Vanete Thomaz Soccol ${ }^{3}$; Ueslei Teodoro ${ }^{2}$

\author{
${ }^{1}$ Setor de Ciências Biológicas, Universidade Estadual do Norte do Paraná - UENP, Campus Luiz Meneghel, Bandeirantes, PR, Brasil \\ ${ }^{2}$ Programa de Pós-graduação em Ciências da Saúde, Universidade Estadual de Maringá - UEM, Maringá, PR, Brasil \\ ${ }_{3}^{3}$ Programa de Pós-graduação em Microbiologia, Parasitologia e Patologia, Departamento de Patologia, Universidade Federal de Paraná \\ - UFPR, Curitiba, PR, Brasil \\ ${ }^{4}$ Departamento de Vigilância em Saúde, Centro de Controle de Zoonoses, Secretaria Municipal de Saúde de Araucária, Araucária, \\ PR, Brasil \\ ${ }_{5}^{5}$ Programa de Pós-graduaçáo em Epidemiologia Experimental Aplicada como Zoonose, Faculdade de Medicina Veterinária, \\ Universidade de São Paulo - USP, São Paulo, SP, Brasil \\ ${ }^{6}$ Departamento de Estatística, Universidade Estadual de Maringá - UEM, Maringá, PR, Brasil \\ ${ }^{7}$ Serviço de Vigilância da Saúde, Ministério da Saúde - MS, Brasília, DF, Brasil
}

Received April 06, 2016

Accepted August 23, 2016

\begin{abstract}
Brazilian spotted fever (BSF) is a fatal zoonosis because of the difficulties in its early diagnosis and treatment. Occurrences of BSF in the northeast of the state of Paraná prompted investigation of areas at risk of this rickettsiosis in the municipalities of Japira, Jaboti, Pinhaláo and Tomazina. To determine the areas at risk, 592 serum samples from dogs and 230 from equids were analyzed by means of the indirect immunofluorescence assay (IFA) for Rickettsia rickettsii and $R$. parkeri. In addition, risk probability maps were drawn up using the kriging indicator technique. Among the samples tested, 5.3\% (43/822) indicated presence of antibodies reactive to at least one of the two Rickettsia species tested: 7.8\% of the equids (18/230) and 4.2\% of the dogs (25/592) were positive. Geostatistical analysis showed that the average seropositivity rate was 5 to $6 \%$. Although the average seropositivity rates observed among these dogs and equids were lower than those reported from endemic areas of Brazil, the biotic components (etiological agent, vector and reservoirs) and environmental aspects of BSF epidemiology were present in these municipalities.
\end{abstract}

Keywords: Rickettsia rickettsii, Rickettsia parkeri, risk map, serology, geostatistical analysis.

\section{Resumo}

A febre maculosa brasileira (FMB) é uma zoonose fatal devido às dificuldades para diagnosticá-la e tratá-la precocemente. A ocorrência de casos de FMB no Estado do Paraná suscitou a investigação de áreas de risco desta rickettsiose nos municípios de Japira, Jaboti, Pinhaláo e Tomazina, na mesorregiáo norte pioneiro do Paraná. Para determinar as áreas de risco foram analisadas amostras de soro de 592 cães e 230 equídeos submetidos à reação de imunofluorescência indireta para Rickettsia rickettsii e $R$. parkeri. Além disto, foram construídos mapas de probabilidade de risco pela técnica de krigagem indicatriz. Das amostras testadas 5,3\% (43/822) continham anticorpos para pelo menos uma das duas rickettsias testadas. Os equídeos apresentaram uma positividade de 7,8\% (18/230) e os cães de 4,2\% (25/592). A análise geoestatística mostrou que a soropositividade média é de 5 a $6 \%$. Embora as soropositividade médias de cães e equídeos constatadas tenham sido menores do que as relatadas em áreas endêmicas do território brasileiro, os componentes bióticos (agente etiológico, vetor e reservatórios) e ambientais da epidemiologia da FMB se fazem presentes nos municípios referidos.

Palavras-chave: Rickettsia rickettsii, Rickettsia parkeri, mapa de risco, sorologia, análise geoestatística.

*Corresponding author: Flávio Haragushiku Otomura. Programa de Pós-graduação em Ciências da Saúde, Universidade Estadual de Maringá

- UEM, Avenida Colombo, 5790, Jardim Universitário, CEP 87020-900,

Maringá, PR, Brasil. e-mail: otomuraflavio@uenp.edu.br 


\section{Introduction}

Generally, little information is available in Paraná state (southern Brazil) for Brazilian Spotted Fever (BSF), a zoonotic disease that can be fatal because of the difficulties involved in early diagnosis and treatment (MONTEIRO et al., 2014). This is the most important rickettsial disease in Brazil and is among the most deadly in the world (FIOL et al., 2010).

The etiological agent of BSF is Rickettsia rickettsii, a Gram-negative obligate intracellular bacterium (LABRUNA, 2009). This species, in the family Rickettsiaceae, is also the agent responsible for Rocky Mountain spotted fever (RMSF) in the USA (PAROLA et al., 2013)

In Brazil from 1997 to May 2014, 1,243 cases of human rickettsiosis were recorded, with 29.28\% lethality (BRASIL, 2014). In the state of Paraná, the first confirmed human case of BSF was informed by the Ministry of Health in 2005 (BRASIL, 2006). Since then, 14 new cases have been recorded, with two deaths (BRASIL, 2014). Besides R. rickettsii (the agent of BSF), a Rickettsia parkeri-like agent, strain Atlantic rainforest, has been recognized to cause spotted fever illness in humans from Santa Catarina and Rio Grande do Sul, southern Brazil (PAROLA et al., 2013; KRAWCZAK et al., 2016; VIZZONI et al., 2016). In addition a R. parkeri-like agent of unknown pathogenicity, strain ApPR, has been detected in Amblyomma parkeri ticks collected from wild birds in the eastern part of the state of Paraná (PACHECO et al., 2012).

BSF is a multisystemic disease, and it is difficult to make a differential diagnosis in relation to non-rickettsial diseases that present fever and rash, such as leptospirosis and dengue (FIOL et al., 2010; MONTEIRO et al., 2014). When the possibility of BSF occurrence is neglected, fatal cases can occur without any definitive diagnosis having been determined (MONTEIRO et al., 2014). The difficulties in diagnosing BSF in humans, especially in its early stages, highlight the importance of characterizing areas with greater possibility of BSF occurrence, in order to enable early diagnosis and prompt treatment (BRASIL, 2010).

Investigations on sources of rickettsial infection or exposure have used the indirect immunofluorescence assay (IFA) to detect anti-rickettsial antibodies in mammals, particularly horses and dogs (HORTA et al., 2004). These animals, with positive serological findings, have been indicated as sentinels in areas endemic for BSF. In addition, horses are primary hosts of the main vector tick, Amblyomma sculptum (NAVA et al., 2014), which commonly infests dogs and, in turn, facilitates infestation of human habitations (FREITAS et al., 2010). Human infection is accidental and depends on tick abundance, when the ticks cohabit the same environment as man (HORTA et al., 2004; SANGIONI et. al., 2005). Lately, incorporation of geoprocessing techniques and spatial analysis in epidemiological studies has become increasingly common (MAGALHÁES, 2012). This improves the visualization of risk areas, thus making it a valuable tool for analysis on disease dynamics and their relationship with the environment (MEDRONHO et al., 2003; MAGALHÂES, 2012).

The notification of BSF cases in the state of Paraná state has given rise to serological investigation of the spotted fever group bacteria in dogs and equids, and geostatistical data analysis, in order to identify likely BSF risk areas in the municipalities of
Japira, Jaboti, Pinhaláo and Tomazina in the northeastern region of the state of Paraná.

\section{Materials and Methods}

This study was conducted in rural areas of the municipalities of Japira (Estrelinha district) $\left(23.81^{\circ} \mathrm{S}, 50.13^{\circ} \mathrm{W}\right)$, Jaboti (Água Branca district) $\left(23.74^{\circ} \mathrm{S}, 50.07^{\circ} \mathrm{W}\right)$, Pinhalão (Pinhaláo riverbank) $\left(23.79^{\circ} \mathrm{S}, 50.05^{\circ} \mathrm{W}\right)$ and Tomazina (Germino district) $\left(23.77^{\circ} \mathrm{S}, 49.95^{\circ} \mathrm{W}\right)$, which are within the northeastern region of the state of Paraná (Figure 1).

They are located in a sedimentary area with topography ranging from mild undulating to wavy, with altitudes of 550-650 meters above sea level, low-fertility soils (red ultisol, oxisol and litholic Neosol) and unfavorable agricultural potential or restrictions primarily in relation to mechanization (IBGE, 2011).

Its weather is mesothermal: humid subtropical, with hot summers and moderate concentration of rainfall in the summers (average temperature above $22^{\circ} \mathrm{C}$ ); winters with infrequent frost (average temperature below $18{ }^{\circ} \mathrm{C}$ ); and no marked dry season (IAPAR, 2014).

The native vegetation belongs to the Atlantic Forest biome, and consists of ombrophilous or semi-deciduous forest. The altered primary forests, along with the secondary, as well as coppices and exotic vegetation (eucalyptus), follow the local hydrography, along with some reserves on the slopes and/or hill tops. Forested areas of permanent preservation or legal reserve in Jaboti have 1,356 hectares, in Japira 1,538 hectares, in Pinhalão 2,550 hectares, and in Tomazina 6,956 hectares (IBGE, 2006).

The hydrography is of dendritic type, with many rivers and streams featuring waterfalls. The valleys are open and the arboreal vegetation (forest) extends beyond the marginal zone to the rivers. Most often, the older residences are located on the lower slopes and valleys, next to the local bodies of water, and the secondary forest or the altered primary forest is located 20 to 30 meters from the streams and riverbanks, which have now been designated as Permanent Preservation Areas.

The blood samples used in this study were from the serum bank of the research project entitled "Can Equids Be a Reservoir of Leishmania braziliensis in Endemic Areas?” The animal research ethics protocol for this project was approved by the National Council for Scientific and Technological Development (CNPq) (procedural no. 301906/2008-4).

Blood samples were collected by means of venous puncture from the dogs' cephalic vein and from the equids' jugular vein. All the samples were identified, placed in cool boxes with ice, and transported to the Basic Parasitology Laboratory of the State University of Maringa. Serum from each blood sample was separated by means of centrifugation at 3,000 rpm for 10 minutes. The serum samples were then divided into aliquots in $1.5 \mathrm{~mL}$ microtubes (Eppendorf), and then stored at $-20^{\circ} \mathrm{C}$. These serum samples were subsequently subjected to indirect immunofluorescence assay (IFA), since this is the serological method most used for determining of possible exposure. This method is also the gold standard of the Ministry of Health, because of its high sensitivity and specificity to spotted fever group rickettsiae (BRASIL, 2010). 


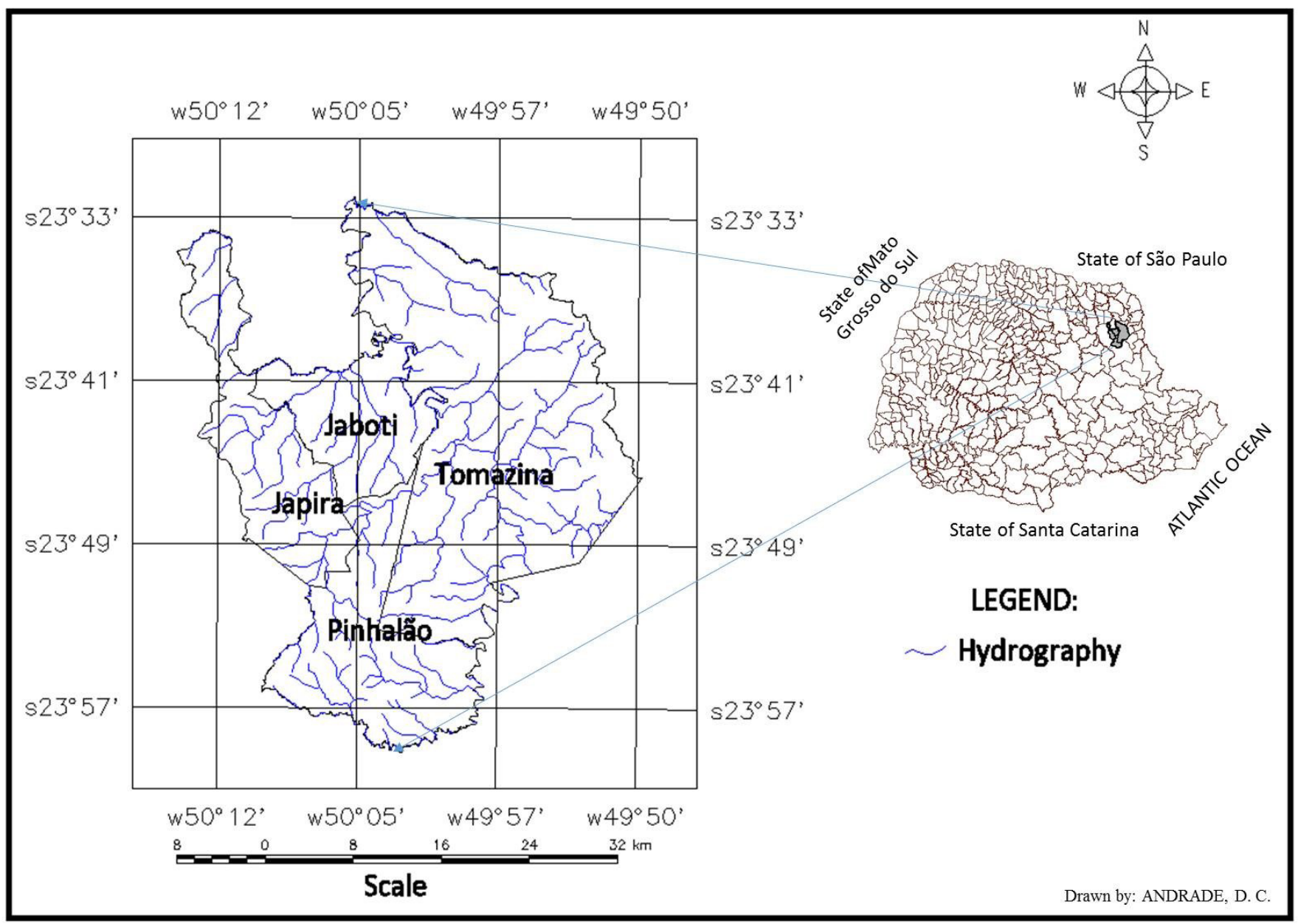

Figure 1. Municipalities in the northeastern area of the state of Paraná, southern Brazil, where the study was conducted.

Slides were prepared and presented at the Clinical Immunology Laboratory of the State University of Maringa. The antigens used were Rickettsia rickettsii (Taiaçu strain) and $R$. parkeri (AT24 strain), provided by the Parasitic Diseases Laboratory of the University of São Paulo (VPS/USP). IFA was performed in accordance with Horta et al. (2004), where known positive and negative sera were used as controls on each lamina. Samples that showed fluorescence were diluted at ratios from 2 to 1:4,096 for antibody endpoint titer determination. Samples with titers $\geq 64$ for $R$. rickettsii and $R$. parkeri were considered positive.

To check the spatial distribution of seropositivity cases, geostatistical techniques were put into action. These assume that the closest spatially correlated data have similar behavior to each other (CARDUCCI et al., 2015). The animals examined were classified as 1 (seropositive) or 0 (seronegative) and, from this, it was possible to determine the areas at risk of BSF occurrence.

To detect spatial dependence, we used the classic semivariance estimator proposed by Matheron (1963). According to Cressie (1993), with a sample $Z\left(x_{i}\right)$, where $i=1,2, \ldots, n$, the semivariance estimator is defined by Equation 1 :

$$
\hat{\gamma}(\mathrm{h})=\frac{1}{2 \mathrm{~N}(\mathrm{~h})} \sum_{\mathrm{i}=1}^{\mathrm{N}(\mathrm{h})}\left[\mathrm{z}\left(\mathrm{x}_{\mathrm{i}}\right)-\mathrm{z}\left(\mathrm{x}_{\mathrm{i}}+\mathrm{h}\right)\right]^{2}
$$

Where:

$\hat{y}(h)$ is the semivariance estimator;

$N(b)$ is the number of measured values in pairs, $Z\left(x_{i}\right)$ and $Z\left(x_{i}+h\right)$, separated by a distance vector $h$;

$Z\left(x_{i}\right)$ and $Z\left(x_{i}+h\right)$ : are realizations of the random variable $Z\left(x_{i}\right)$, i.e. values of the $\mathrm{i}^{\text {th }}$ observation of the regionalized variable, collected at the $x_{i}$ points and $\left(x_{i}+h\right)$, with $i=1,2, \ldots$, n, separated by the $h$ vector.

From the adjusted model and indicative variables ( $1=$ seropositive and $0=$ seronegative) it was possible to draw up a probability map using the indicator kriging technique. According to Verhagen \& Bouma (1997), cited by Motomiya et al. (2006), the indicator kriging technique has been successful because it allows expression of the spatial model in terms of probability.

All statistical analyses were performed using the R software (R DEVELOPMENT CORE TEAM, 2012).

\section{Results}

From March to November 2009, 592 blood samples from dogs, 230 from equids ( 185 horses and 45 donkeys), thus totaling 822 samples (Table 1), were collected. The ages of the dogs ranged from two months to 15 years; horses, from six months 
Table 1. Seropositive dogs and equids to spotted fever group rickettsiae (Rickettsia parkeri and/or R. rickettsia) detected by means of indirect immunofluorescence in municipalities in the northeastern area of the state of Paraná, Brazil.

\begin{tabular}{|c|c|c|c|c|}
\hline \multirow{2}{*}{ Municipality } & \multicolumn{3}{|c|}{ Seropositive animals / animals tested (\% positive) } & \multirow{2}{*}{ Total } \\
\hline & Horses & Donkeys & Dogs & \\
\hline Japira & $7 / 61(11.5)$ & $2 / 17(11.8)$ & $8 / 181(4.4)$ & $17 / 259(6.6)$ \\
\hline Jaboti & $5 / 50(10.0)$ & $0 / 9(0.0)$ & $6 / 128(4.7)$ & $11 / 187(5.9)$ \\
\hline Pinhalão & $2 / 35(5.7)$ & $0 / 4(0.0)$ & $6 / 165(3.6)$ & $9 / 204(3.9)$ \\
\hline Tomazina & $2 / 39(5.7)$ & $0 / 15(0.0)$ & $5 / 118(4.2)$ & $7 / 172(4.1)$ \\
\hline Total & $16 / 185(8.6)$ & $2 / 45(4.4)$ & $25 / 592(4.2)$ & $43 / 822(5.3)$ \\
\hline
\end{tabular}

to 20 years; and donkeys, from three to 19 years. All the animals were apparently healthy.

These 822 serum samples from dogs, horses and donkeys were tested by means of IFA. Among them, 43 (5.3\%) contained antibodies that reacted with $R$. rickettsii and/or $R$. parkeri, taking the titer of 64 as the cutoff point (Table 1).

Among the 185 horses tested, 16 (8.6\%) demonstrated positive titers, of which three $(18.7 \%)$ had titers of 64 , two $(12.5 \%)$ had titers of 128 , two $(12.5 \%)$ had titers of 256 and one $(6.25 \%)$ had a titer of 256 for $R$. rickettsii; five $(31.5 \%)$ were reactive to $R$. parkeri with a titer of 64, and three reacted to both Rickettsia species tested, with titers ranging from 64 to 2,048 for $R$. rickettsii and from 64 to 256 for $R$. parkeri. Among the 45 donkeys sampled, two (4.4\%) had titers of 128 for $R$. rickettsii (Table 2 ).

Among the 592 dog samples subjected to IFA, 25 (4.2\%) had titers that were reactive to the Rickettsia species tested. Of these, twelve samples (48\%) reacted only to $R$. rickettsii, with titers ranging between 64 and 128; and six (24\%) had titers against $R$. parkeri ranging from 64 to 256 . Of the serum samples, seven (28\%) reacted to both of the Rickettsia species tested, with titers ranging from 64 to 512. The positive canine samples (C007, C195, C416 and C057) had titers from 128 to 512 against the $R$. parkeri antigen. In three other canine samples (C276, C289 and C062), titers of 128 against $R$. rickettsii were found (Table 2 ).

Geostatistical analysis on the results showed that the average seropositivity rate was 5 to $6 \%$ in all the four municipalities, and that the greatest probability of seropositivity occurred in the south-central area of Japira, along with the southeast of Jaboti, with seropositivity rates of $8 \%$ (Figure 2 ). Considering only the seropositive dogs, the average seropositivity rate was $6 \%$. The areas of greatest probability of seropositivity were the north and south-central areas of Japira, east of Jaboti, southeast of Pinhalão and central-west of Tomazina (Figure 3 and 4).

\section{Discussion}

Although the first report of BSF in Brazil was in 1929, the disease was not notified in Paraná until 2005, when the first human case appeared in São José dos Pinhais (BRASIL, 2006; FREITAS et al., 2010). Thereafter, 14 cases were reported in districts of 13 municipalities, with two deaths from complications: one in the municipality of Andirá and another in Leópolis (BRASIL, 2014), both located in the northeastern region of the state of Paraná.

Most of the 43 seropositive samples (titers $\geq 64$ ) in the present study (Table 2 ) reacted with to both $R$. rickettsii and $R$. parkeri antigens, which are agents that cause spotted fever illness in Brazil
Table 2. Anti-rickettsial antibody titers detected through indirect immunofluorescence assay in dogs and equids from municipalities in the northeastern area of the state of Paraná, Brazil.

\begin{tabular}{ccccc}
\hline Animal & Animal & Municipality & Antibody titers \\
\cline { 4 - 5 } identification & species & rickettsii & Rickettsia \\
parkeri
\end{tabular}




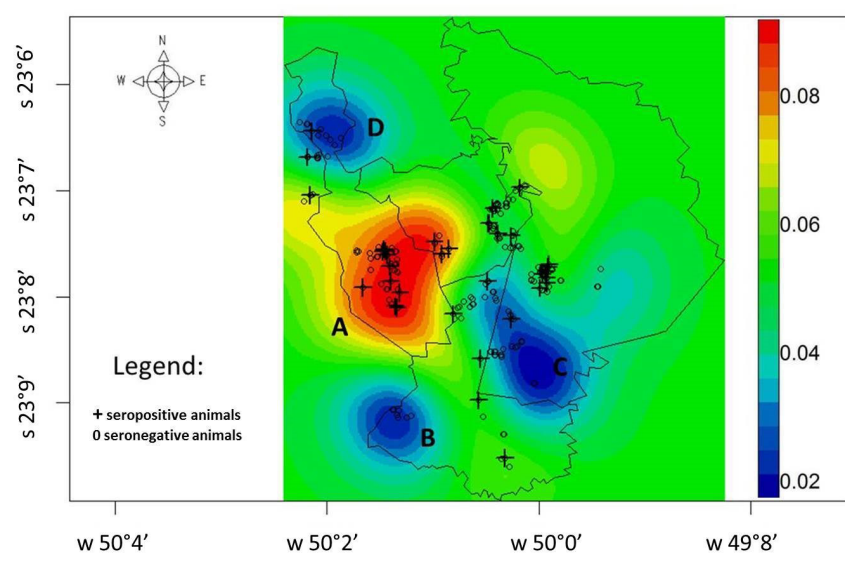

Figure 2. Dogs and equids with seropositivity to spotted fever group rickettsiae in municipalities where spotted fever group infection may occur, in the northeastern area of the state of Paraná, Brazil.

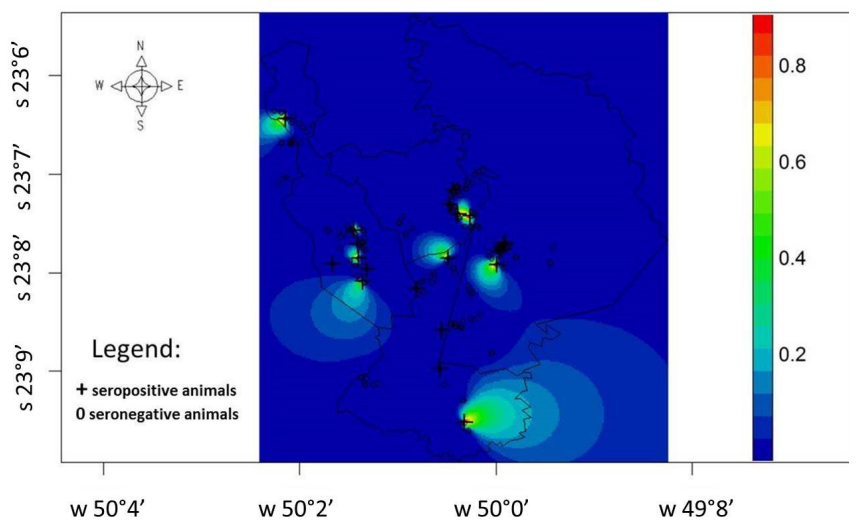

Figure 3. Spatial distribution of rates of rickettsial seropositivity to spotted fever group rickettsiae among sampled dogs and probability of occurrence of spotted fever group infection in municipalities in the northeastern area of the state of Paraná, Brazil.

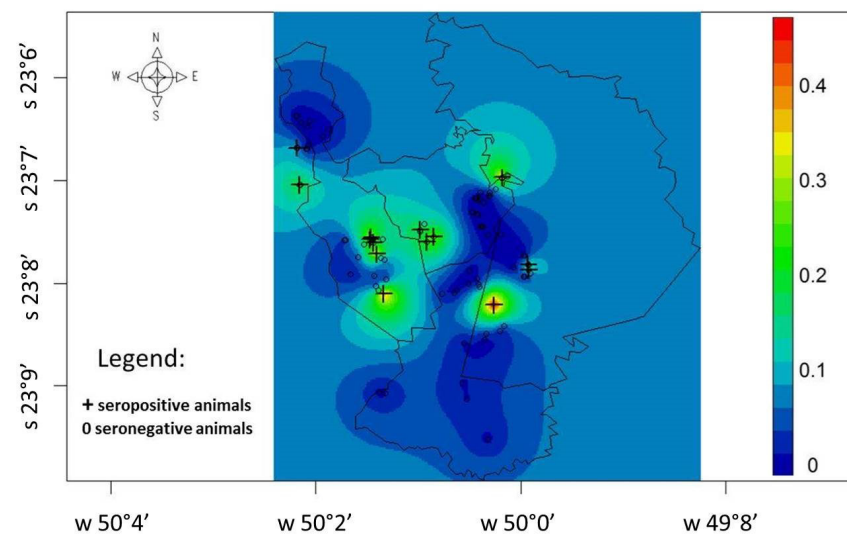

Figure 4. Spatial distribution of rates of rickettsial seropositivity to spotted fever group rickettsiae among sampled equids and probability of occurrence of spotted fever group infection in municipalities in the northeastern area of the state of Paraná, Brazil. and other American countries (PAROLA et al., 2013). However, because serologic cross-reactions are well known to occur between different Rickettsia species of the spotted fever group (PAROLA et al., 2013), the seropositive results of the present study are technically interpreted as seropositive to spotted fever group rickettsiae, which could include other Rickettsia species from the spotted fever group besides $R$. rickettsii and $R$. parkeri.

The geostatistical analysis showed that the spatial distribution of seropositive dogs and equids was homogeneous, with an average annual probability of seropositivity close to $6 \%$. However, the northern area of Japira, (D), south of Tomazina (C) and southwest of Pinhalão (B) differed from this pattern, with seropositivity probability of about $2 \%$. The south-central area of Japira and southwest of Jaboti (A) showed seropositivity probabilities of 6 to $8 \%$ (Figure 2) with the highest risk area. According to Magalhães (2012) spatial analysis ultimately enables the identification of health problems in risk areas.

The areas with greatest probability of seropositivity to spotted fever group rickettsiae in dogs and equids were almost the same. The exceptions were the north of Japira, southeast of Jaboti and south of Pinhalão, with seropositivity probabilities of 4 to $8 \%$ among dogs (Figure 3); and the northwest area of Tomazina with seropositivity probability of 2 to $4 \%$ among horses (Figure 4). In area $\mathrm{A}$, with higher seropositivity probability for dogs and equids analyzed individually (Figures 3 and 4), it should be noted that the seropositivity probability for dogs ranged from 0 to $8 \%$, while for equids, the range was from 0 to $4 \%$. Interestingly, this area has an areas of about $88 \mathrm{~km}^{2}$ and is located between the Iguape and Patrimônio streams, where sugarcane, cassava, corn and bean crops can be seen, along with forest remnants, which together may be the biggest risk factors in area $\mathrm{A}$. The presence of rivers, with crop areas and a few areas of native forest, has a strong correlation with BSF (RIBEIRO et al., 2013; BARROS E SILVA et al., 2014). According to Fortes et al. (2010), this type of environment favors development of capybaras, which are a competent amplifier host for Rickettsia species of the spotted fever group and are one of the main hosts of the tick vector, Amblyomma sculptum (LABRUNA, 2009; NAVA et al., 2014).

The data presented here confirm the results obtained from other studies conducted in the state of Paraná, through verifying the presence of anti-rickettsial antibodies in human, equine and canine serum samples for two or more Rickettsia species, especially $R$. rickettsii and $R$. parkeri. These other studies indicated positive rates ranging from 5.5 to $38.5 \%$ in horses, from 0 to $19.1 \%$ in dogs and from 4.7 to $21.0 \%$ in humans (BATISTA et al., 2010; FREITAS et al., 2010; OTOMURA et al., 2010; TAMEKUNI et al., 2010; TAMEKUNI et al., 2011; TOLEDO et al., 2011), according to the geographic area. The low prevalence found in this study suggests that dogs and horses are exposed to a small vector population infected by Rickettsiae. However, data obtained by Fortes et al. (2010) and Freitas et al. (2010) show that, even in regions where there is low prevalence of seropositive dogs and equids, human cases of BSF may occur.

The spatial proximity of the municipalities of Japira, Jaboti, Pinhalão and Tomazina to areas that are endemic for BSF in municipalities in the southwest of the state of Sao Paulo (RIBEIRO et al., 2013), existence of risk factors such as the 
presence of capybaras (reported by the majority of the owners of the animals sampled) and the availability of competent vectors (LABRUNA, 2009; NAVA et al., 2014) suggest the hypothesis that areas at risk of BSF exist in these municipalities. Thus, these factors draw healthcare professionals' attention towards making a distinction between BSF and other febrile rash illnesses. The state Health Department thus needs to investigate the presence of the etiological agent, using human, equids and canine serological tests, and/or detection of rickettsial infection in ticks and wild animals, in municipalities of the state of Paraná where human cases of this disease were reported (BRASIL, 2006) and in those with environmental features that fit the epidemiology of BSF. It is important to note that other rickettsiae have been described as BSF causal factors, such as the Rickettsia sp. strain Atlantic rainforest (BARBIERI et al., 2014). Moreover, not only A. sculptum is responsible for transmitting BSF but other species of ticks may also play a role (e.g. A. ovale and $A$. triste) (SABATINI et al., 2010; SZABÓ et al., 2013; BARBIERI et al., 2014; MONJE et al., 2016).

The spotted fever group Rickettsia-seropositivity in domestic animals and the probability of risk detected through geostatistical analysis suggests that there is low rickettsial activity in the municipalities of Japira, Jaboti, Pinhalão and Tomazina. Although the average rates of seropositivity in dogs and equids were lower than those reported in endemic areas of Brazil, the biotic components (etiological agent, vector and reservoirs), and environmental aspects of BSF epidemiology are present in these municipalities. Thus it is necessary to conduct further studies including other rickettsial antigens or a large scale molecular survey (Polymerase Chain Reaction - PCR - and sequencing) in humans, animals and ticks to better identify which Rickettsia species is eliciting these serological responses.

\section{References}

Barbieri AR, Filho JM, Nieri-Bastos FA, Souza JC Jr, Szabó MP, Labruna MB. Epidemiology of Rickettsia sp. strain Atlantic rainforest in a spotted fever-endemic area of southern Brazil. Ticks Tick Borne Dis 2014; 5(6): 848-853. PMid:25108786. http://dx.doi.org/10.1016/j.ttbdis.2014.07.010.

Barros e Silva PMR, Pereira SVC, Fonseca LX, Maniglia FVP, Oliveira SV, Caldas EP. Febre maculosa: uma análise epidemiológica dos registros do sistema de vigilância do Brasil. Scient Plena 2014; 10(4): 1-9.

Batista FG, Silva DM, Green KT, Tezza LBL, Vasconcelos SP, Carvalho SGS, et al. Serological survey of Rickettsia sp. in horses and dogs in an non-endemic area in Brazil. Rev Bras Parasitol Vet 2010; 19(4): 205-209. PMid:21184695. http://dx.doi.org/10.1590/S1984-29612010000400003.

Brasil. Ministério da Saúde. Sistema nacional de vigilância em saúde: relatório de situaçâo: Paraná [online]. Brasília: MS; 2006. [cited 2014 Dec 22]. Available from: <http://bvsms.saude.gov.br/bvs/publicacoes/ sistema_nacional_vigilancia_saude_pr_5ed.pdf

Brasil. Ministério da Saúde. Secretária de Vigilância em Saúde. Departamento de Vigilância Epidemiológica. Doenças infecciosas e parasitárias: guia de bolso [online] 8. ed. Brasília: MS; 2010 [cited 2014 Dec 23]. Available from: http://bvsms.saude.gov.br/bvs/publicacoes/doencas_infecciosas_ parasitaria_guia_bolso.pdf

Brasil. Ministério da Saúde. Portal Saúde. Febre maculosa: situação epidemiológica [online]. Brasília: MS; 2014. [cited 2014 Dec 23].
Available from: http://portalsaude.saude.gov.br/index.php/o-ministerio/ principal/leia-mais-o-ministerio/693-secretaria-svs/vigilancia-de-a-a-z/ febre-maculosa/11269-situacao-epidemiologica-dados

Carducci CE, Oliveira GC, Curi N, Heck RJ, Rossoni DF, Carvalho TS, et al. Gypsum effects on the spatial distribution of coffee roots and the pores system in oxidic Brazilian Latosol. Soil Tillage Res 2015; 145: 171-180. http://dx.doi.org/10.1016/j.still.2014.09.015.

Cressie N. Statistics for spatial data. New York: John Wiley \& Sons; 1993.

Fiol FSD, Junqueira FM, Rocha MCP, Toledo MI, Barberato S Fo. A febre maculosa no Brasil. Rev Panam Salud Publica 2010; 27(6): 461-466. PMid:20721447. http://dx.doi.org/10.1590/S1020-49892010000600008.

Fortes FS, Silveira I, Moraes-Filho J, Leite RV, Bonacim JE, Biondo AW, et al. Seroprevalence of Rickettsia belli and Rickettsia felis in dogs, São José dos Pinhais, state of Paraná, Brazil. Rev Bras Parasitol Vet 2010; 19(4): 222-227. PMid:21184698. http://dx.doi.org/10.1590/S198429612010000400006.

Freitas MCDO, Grycajuk M, Molento MB, Bonacin J, Labruna MB, Pacheco RC, et al. Brazilian Spotted Fever in cart horse in a non-endemic area in southern Brazil. Rev Bras Parasitol Vet 2010; 19(2): 130-131. PMid:20624353. http://dx.doi.org/10.4322/rbpv.01902013.

Horta MC, Labruna MB, Sangioni LA, Vianna MCB, Gennari SM, Galvão MAM, et al. Prevalence of antibodies to Spotted Fever Group Rickettsiae in humans and domestic animals in a Brazilian Spotted Fever: endemic area in the state of São Paulo, Brazil: serologic evidence for infection by Rickettsia rickettsii and another Spotted Fever Group Rickettsia. Am J Trop Med Hyg 2004; 71(1): 93-97. PMid:15238696.

Instituto Agronômico do Paraná - IAPAR. Cartas climáticas do Paraná [online]. 2014 [cited 2014 Dec 17]. Available from: http://www.iapar. $\mathrm{br} /$ modules/conteudo/conteudo.php?conteudo $=597$

Instituto Brasileiro de Geografia e Estatística - IBGE. Censo agropecuário de 2006 [online]. Paraná: IBGE; 2006 [cited 2015 Mar 4]. Available from: http://cidades.ibge.gov.br/xtras/perfil.php?lang=\&codmun=410970

Instituto Brasileiro de Geografia e Estatística - IBGE. Mapas interativos do IBGE [online]. 2011 [cited 2011 Jun 15]. Available from: http:// mapas.ibge.gov.br/

Krawczak FS, Muńoz-Leal S, Guztzazky AC, Oliveira SV, Santos FCP, Moraes-Filho J, et al. Rickettsia sp. Strain Atlantic Rainforest infection in a patient from a spotted fever-endemic area in southern Brazil. Am J Trop Med Hyg 2016; 95(3): 551-553. PMid:27325804. http://dx.doi. org/10.4269/ajtmh.16-0192.

Labruna MB. Ecology of Rickettsia in South America. Ann NY Acad Sci 2009; 1166(1): 156-166. PMid:19538276. http://dx.doi.org/10.1111/ j.1749-6632.2009.04516.x.

Magalhães GB. O uso do geoprocessamento e da estatística nos estudos ecológicos em epidemiologia: o caso da dengue em 2008 na região metropolitana de Fortaleza. Hygeia 2012; 8(15): 63-77.

Matheron G. Principles of geostatistics. Econ Geol 1963; 58(8): 12461266. http://dx.doi.org/10.2113/gsecongeo.58.8.1246.

Medronho RA, Valencia LIO, Fortes BPMD, Braga RCC, Ribeiro SV. Análise espacial da soroprevalência da hepatite A em crianças de uma regiāo carente de Duque de Caxias, RJ, Brazil. Rev Bras Epidemiol 2003; 6(4): 328-334. http://dx.doi.org/10.1590/S1415-790X2003000400007.

Monje LD, Costa FB, Colombo VC, Labruna MB, Antoniazzi LR, Gamietea I, et al. Dynamics of Exposure to Rickettsia parkeri in Cattle in the Paraná River Delta, Argentina. J Med Entomol [Epub ahead of print] 
2016; 53(3): 660-665. PMid:26794232. http://dx.doi.org/10.1093/ jme/tjv250.

Monteiro KJL, Rozental TR, Lemos ERS. Diagnóstico diferencial entre febre maculosa brasileira e o dengue no contexto das doenças febris agudas. Rev Patol Trop 2014; 43(3): 241-250.

Motomiya AVA, Corá JE, Pereira GT. Uso da krigagem indicatriz na avaliação de indicadores de fertilidade do solo. Rev Bras Cienc Solo 2006; 30(3): 485-496. http://dx.doi.org/10.1590/S0100-06832006000300010.

Nava S, Beati L, Labruna MB, Cáceres AG, Mangold AJ, Guglielmone AA. Reassessment of the taxonomic status of Amblyomma cajennense (Fabricius, 1787) with the description of three new species, Amblyomma tonelliae n. sp., Amblyomma interandinum n. sp. and Amblyomma patino n. sp., and reinstatement of Amblyomma mixtum Koch, 1844 and Amblyomma sculptum Berlese, 1888 (Ixodida: Ixodidae). Ticks Tick Borne Dis 2014; 5(3): 252-276. PMid:24556273. http://dx.doi.org/10.1016/j. ttbdis.2013.11.004.

Otomura FH, Sangioni LA, Pacheco RC, Labruna MB, Galhardo JA, Ribeiro MG, et al. Anticorpos anti-rickettsias do grupo da febre maculosa em equídeos e caninos no norte do Estado do Paraná, Brasil. Arq Bras Med Vet Zootec 2010; 62(3): 761-764. http://dx.doi.org/10.1590/S010209352010000300037.

Pacheco RC, Arzua M, Nieri-Bastos FA, Moraes-Filho J, Marcili A, Richtzenhain LJ, et al. Rickettsial infection in ticks (Acari: Ixodidae) collected on birds in southern Brazil. J Med Entomol 2012; 49(3): 710 716. PMid:22679880. http://dx.doi.org/10.1603/ME11217.

Parola P, Paddock CD, Socolovschi C, Labruna MB, Mediannikov O, Kernif T, et al. Update on tick-borne Rickettioses around the world: a Geographic approach. Clin Microbiol Rev 2013; 26(4): 657-702. PMid:24092850. http://dx.doi.org/10.1128/CMR.00032-13.

R Development Core Team. R: A language and environment for statistical computing [online]. Viena: R Foundation for Statistical Computing, 2012 [cited 2015 Mar 4]. Available from: http://www.r-project.org/.

Ribeiro MD, Furtado MA, Ferraudo AS, Cesario M, Morraye MA. Fatores ambientais envolvidos na epidemiologia da febre maculosa no estado de São Paulo. Hygeia 2013; 9(16): 103-114.
Sabatini GS, Pinter A, Nieri-Bastos FA, Marcili A, Labruna MB. Survey of ticks (Acari: Ixodidae) and their Rickettsia in an Atlantic rain forest reserve in the State of São Paulo, Brazil. J Med Entomol 2010; 47(5): 913-916. PMid:20939390. http://dx.doi.org/10.1603/ME10073.

Sangioni LA, Horta MC, Vianna MCB, Gennari SM, Soares RM, Galvão MAM, et al. Rickettsial infection in animals and Brazilian Spotted Fever endemicity. Emerg Infect Dis 2005; 11(2): 265-270. PMid:15752445. http://dx.doi.org/10.3201/eid1102.040656.

Szabó MP, Pinter A, Labruna MB. Ecology, biology and distribution of spotted-fever tick vectors in Brazil. Front Cell Infect Microbiol 2013; 3: 27. PMid:23875178. http://dx.doi.org/10.3389/fcimb.2013.00027.

Tamekuni K, Toledo RS, Silva MF Fo, Haydu VB, Pacheco RC, Cavicchioli $\mathrm{JH}$, et al. Serosurvey of antibodies against Spotted Fever Group Rickettsia spp. in horse farms in Northern Paraná, Brazil. Rev Bras Parasitol Vet 2010; 19(4): 259-261. PMid:21184706. http://dx.doi.org/10.1590/ S1984-29612010000400014.

Tamekuni K, Toledo RS, Silva-Filho MF, Haydu VB, Pacheco RC, Labruna $\mathrm{MB}$, et al. Survey of rickettsiae in humans, dogs, horses, and ticks in northen Paraná, Brazil. Semina: Ciênc Agrár 2011; 32(4): 1527-1538.

Toledo RS, Tamekuni K, Silva-Filho MF, Haydu VB, Barbieri ARM, Hiltel AC, et al. Infection by Spotted Fever Rickettsiae in people, dogs, horses and ticks in Londrina, Paraná state, Brazil. Zoonoses Public Health 2011; 58(6): 416-423. PMid:21824336. http://dx.doi.org/10.1111/j.18632378.2010.01382.x.

Verhagen J, Bouma J. Modeling soil variability. In: Pierce JF, Sadler EJ. The state of site-specific management for agriculture. Madison: American Society of Agronomy; 1997. p. 55-68.

Vizzoni VF, Silva AB, Cardoso KM, Santos FB, Stenzel B, Amorim M, et al. Genetic identification of Rickettsia sp.strain Atlantic rainforest in an endemic area of a mild spotted fever in Rio Grande do Sul State, Southern Brazil. Acta Trop 2016; 162: 142-145. PMid:27338183. http:// dx.doi.org/10.1016/j.actatropica.2016.06.018. 